\title{
Evaluation of the algal biodiversity of the ruparael area of the Alwar district of Rajasthan
}

\begin{abstract}
Algae are the heterogeneous group of the organisms, they have the profound effects of the different types of the ecosystem on the earth as well as on the aquatic ecosystem, they are existing on the earth from the billions of years and they have profound effects on the world biogeochemistry. In addition to the oxygen they produce large amount of the organic carbon on the earth biogeochemical cycle. Algae have the Varity of the role in the earth biogeochemical cycles, they are form the single cells to the multicellular filamentous gigantism thallus. Algae are the major contributors of the world biodiversity, the estimated number of the large biodiversity ranges from the 36000 , to around of the one millions. Each species has the unique traits and they play a major role in the world biodiversity.

Algae are attached with the other organism with the way of the food web, biogeochemcal cyclers and the symbiotic associations. Here in this research paper we are presenting algal biodiversity of the one of the river area of the alwar district of Rajasthan in the rupareal area of the alwar Rajasthan. The river is the epimeheral and it follows around the 12 month, although the amount of the water is scared in the summer, we have try to enumerate the biodiversity of the algae are of that river in the different seasons and ewe found the considerable diversity. Total of the 10 genera's have been found in the algae river area. Some of the genera's also shows the pollution indicators.
\end{abstract}

Volume 2 Issue 3 - 2018

\section{Teena Agrawal}

Banasthali University, India

Correspondence: Teena agrawal,Assistant Professor, Banasthali University, Newai, Rajasthan, India, Email tagrawal02@gmail.com

Received: March 29, 2018 | Published: June 27, 2018

Keywords: algae, heterogeneous, biodiversity, ruparaeal river, algal genera's, pollution indicators, different seasons.

\section{Introduction}

Algae are the heterogeneous assemblage of the organisms, which ranges from the sizes form the singe cells to the giant thallus. The length of the thallus ranges from the filamentous to the large kelps which covers the several meters area of the sea in India as well as the other parts of the world. The algae are the most photosynthetic species, produces mostly the oxygen's, they lives in the aquatic habitat. The algae lack the body of the higher plants as well as the other feathers of the higher plants. The photosynthetic features of the algae includes the eukaryotes as well as the prokaryotes natures, the prokaryotes natures includes the cyanobacteria. Theses have been termed as the blue green algae. Algae occurs in the several body types, algal body are to small that we need to use the microscope for the clear visibility, theses algae have been termed as the microalgae. Algal body which are macroscopic and they covers the large area in the aquatic body are termed as the macro algae. many microalgae lives as the single cells, some of the algae are in the round shaped and they occurs in the coccid forms, some of the coccid forms together forms the colonies. In the coenobium has the definite number of the cells in the colony, some of the algae are propelled by the flagella and they have been termed as the flagellates. ${ }^{1-5}$ Other features of the algae are they are filamentous; the cells are attached from one to one by the end. Some of the microalgae genera's are the periphyton and some of the algae are the phytoplankton, periphyton are attached to the some of the substratum in the aquatic body while the phytoplankton are free swimming kinds of the microalgae. ${ }^{6,7}$ Algae reproduce by the, means of the asexual and the sexual methods. Asexual reproduction occurs by the various means of the spores, these are the zoospores and the non motile aplanospores, the whole of the cytoplasm of the aplanospores are converted in to the nonmotiles aplanospores. The alternation of the generation is two types, one of them is the isomorphic alternation and another is the heteromorphy alternation of the generations. Algae has been classified in the various way, some of the common way for the classifying the algal genera's are the types of the storage foods as well as the Types of the flagella and the types if he pigmentation. Algae play a great role in the biogeochemistry, they also are the valuable part of the earth biogeochemical cycle. Algae are present in the sea, oceans as well as in the moisture environment. Some of the algae are the typical pollution indicators; some of the species of the algae are present in the environment which is rich of the many kind of the pollutants, so they act as the indicator of the high amount of the pollutions in the concerned sea or in the concerned rivers. The body of the algae is very primitive, they lack the true roots, stem, leaves and other kinds of the fruiting body, theses features are very characterises for the higher plants. ${ }^{1-5}$ Marine algae are very valuable and they are the rich sources of food, and they are also the very rich sources of the vitamins, mineral, and other kinds of the metabolites. Many of the algae are also used as the sources of the pharmaceuticals in the form of the medicines, however algae genera's are the potential sources of the many kinds of the food resources as well as some of the medicines as well as they are the sources of the environmental indicators ${ }^{8-15}$ Some of the algae genera's such as the Stigcolonium, Nitzia, Gomphonema, Cocoonei, Navicula, ulothrix. In addition to that many other genera also function as the pollution indicator. ${ }^{11,12,15,16-23}$

\section{Material and methods}

Algal samples were collected in the plastic bags, the water sample were collected from the differ places from the different height of the river as well as from the different seasons. For the study purposes the river rupareal was selected, the river is the ephemeral and the water flows in the river in the 12 month. However the frequency of the water detertiotes the typical summer seasons, in the rainy seasons ands in 
the winter seasons the algal biodiversity reaches at its peaks, in the middle of the river maximum biodiversity can be seen, the water with the algae were carefully seen and the genera were identified with the help of the monograph of the Geroge 1976,as well as the monograph Lund1960, Swate 1978. after taking the sample form the river the sample were washed with the tap water, so that he debris can be eradicated and the whole of the sample is preserved in the $4 \%$ formalin and iodine solution. Alwar is the region in the arawali areas, there are very few rivers and lakes since it is present in the dry part of the city.

\section{Result and discussion}

The study in the river indicates the presence of them any kinds of the genera's, theses algae genera are of the filamentous kinds and sometimes in excess of the water they forms the algal-blooms. The sites also contain many kinds of the microalgae, they are sometimes as the phytoplankton and sometime they are as the periphyton. Some of the algae genera's are as indentified as:

I. Ulothrix: The genus is collected from the upper region of the river and $\mathrm{i}$ is the best filamentous algae, the genus belongs to the ulotricales order, they are unbranched simple filaments, the chloroplast of the cells are simple and they covers the whole of the area of the cells, like the member of the chlorococcales. they are as the periphyton when young but become the free floating when the member young and they detach.

II. Chlamydomonas: They belongs to the class chlamydomonacae the feastures of gthe chlamydsomonas are very similar to the typical member.

III. Avicula: The species are not abundant,they are present only in the scattered patches. The diatoms have two walves, two kinds of the silica frustules with the silica walls. The morphology of the genera's like the typical diatoms.

\section{Chlorella}

V. Volvox: Volvox is the member of the Volvocaceae family, in the colony there are about the 4-32 cells are present and they forms the colony.

VI. Rivularia: The genera have the more or less mucilaginous sheath.

\section{Conclusion}

Overall this is the short work on the algae distribution in the alwar district of Rajasthan, the algae are large world and a lot of the work can be done on it, however there are huge seasonal variations in the algae composition in the river area. Some of the genera are of dominant and they form the large net on the water body. They are very valuable in the ecological cycles of the water body. However a large production never occurs so they cannot be utilised as the sources of the food and the other purposes. In soil microbiology they may lay a vital role but more research work needs to be done. ${ }^{24-26}$

\section{Acknowledgments}

The author is thankful to the Banasthali University for providing the research work in the labs and the govt of Alwar for taking the water Sample from it.

\section{Conflict of interest}

Author declares there is no conflict of interest in publishing the article.

\section{References}

1. George EA, A guide to the algal keys. British Phyocological journal. 1976;11(1):49-85.

2. Lund JWG. The macroscopically examination of the water bodies. Proceedings of the water society of the water treatment. 1960;9(2):109-144.

3. Thakur HA, Behere KH. The study of the algal biodiversity of the gangapur Dam Nasik district. The 12 world lake conferences; 2008. p. 456-461.

4. Archibald REM. Diversity in some South-African Diatom association's and it's relation to water quality. Water Research. 1972;6(10):1229-1238.

5. Wilhm JL. Range of diversity in benthic macroinvertebrate populations. $J$ Water Pollut Control Federation. 1970;42(5):R22I-R224.

6. Edwards RW, Hughes BD, Read MW. Biological survey in the detection and assessment of pollution. In: Chadwick, Goldman, editors. The Ecology of Resource Degradation and Renewal. Symp. British Ecol Soc; 1975. pp. 139-156.

7. Lackey JB. Transactions of a seminar on the biological problems in water pollution. 50 Cincinnati, Ohio: Held at Robert A. Taft Sanitary, Engg Centre; 1957.

8. Kottelat M, Whitten T. Freshwater biodiversity in Asia: with special reference to fish. World Bank Publications; 1996. 59. p.

9. Aguirre J, Riding R. Dasycladalean algal biodiversity compared with global variations in temperature and sea level over the past $350 \mathrm{Myr}$. Palaios. 2005;20(6);581-588.

10. Kerswell AP. Global biodiversity patterns of benthic marine algae. Ecology. 2006;87(10):2479-2488.

11. Sherwood AR, Kurihara A, Conklin KY, et al. The Hawaiian Rhodophyta Biodiversity Survey (2006-2010): a summary of principal findings. BMC plant biology. 2010;10(1):258.

12. Ács É, Szabó K, Tóth B, et al. Investigation of benthic algal communities, especially diatoms of some Hungarian streams in connection with reference conditions of the Water Framework Directives. Acta Botanica Hungarica. 2004;46(3-4):255-278.

13. Naeem S, Li S. Biodiversity enhances ecosystem reliability. Nature. 1997;390(6659):507-509.

14. Corliss JO. Biodiversity and biocomplexity of the protists and an overview of their significant roles in maintenance of our biosphere. Acta Protozoologica. 2002;41(3):199-220.

15. Broady PA. Diversity, distribution and dispersal of Antarctic terrestrial algae. Biodiversity \& Conservation. 1996;5(11):1307-1335.

16. Wernberg T, Smale DA, Tuya F, et al. An extreme climatic event alters marine ecosystem structure in a global biodiversity hotspot. Nature Climate Change. 2013;3(1):78

17. Worm B, Duffy JE. Biodiversity, productivity and stability in real food webs. Trends in Ecology \& Evolution. 2003;18(12):628-632.

18. Thajuddin N, Subramanian G. Cyanobacterial biodiversity and potential applications in biotechnology. Current Science. 2005;89(1):47-57.

19. Muthukumar C, Muralitharan G, Vijayakumar R, et al. Cyanobacterial biodiversity from different freshwater ponds of Thanjavur, Tamilnadu (India); 2007. 
20. Norton TA, Melkonian M, Andersen RA. Algal biodiversity. Phycologia. 1996;35(4):308-326.

21. Ros MD, Marín-Murcia JP, Aboal M. Biodiversity of diatom assemblages in a Mediterranean semiarid stream: implications for conservation. Marine and Freshwater Research. 2009;60(1):14-24.

22. Anand N. Indian Freshwater Microalgae. Bishen Singh Mahendra Pal Singh, Dehra Dun, India; 1998. 94. p.

23. Desikachary TV. Cyanophyta. Indian Council of Agricultural Research, New Delhi; 1959.
24. Dwivedi BK, Pandey GC. Physicochemical factors and algal diversity of two ponds (Girija Kund and Maqubara Pond), Faizabad, India. PollRes. 2002;21(3):361-369.

25. Krishnamurthy V. Algae of India and neighbouring countries. Chlorophycota Oxford \& IBH Publishing Co. Pvt Ltd. New Delhi; 2000.

26. Wilhm JL. Effect of sample size on Shannon's formula. South Western Naturalist. 1970;14(4):441-445. 